\title{
Small Farm Food Safety, Fresh Produce: Instructions for Trainer 1
}

Brian Lapinski, Amy Simonne and M.E. Swisher ${ }^{2}$

\section{What is it?}

Small Farm Food Safety: Fresh Produce is a short, interactive training program that introduces food safety concepts as applied to fresh produce. The concepts are based on the FDA's Guide to Minimized Microbial Food Safety Hazards for Fresh Fruits and Vegetables (FDA-GAPs). The program introduces participants to principles that summarize key concepts in the FDA-GAPs. These are termed the P.A.C.E. principles. The P.A.C.E. principles are basically a simplified version of the FDA-GAPs used in the prevention of microbial contamination in the small farm setting. This training is not intended to be a comprehensive review of the FDA-GAPs, but it does provide an introduction to food safety concepts that are important for small farmers. We hope the training will encourage small farm operators and their employees to "think food safety" in their work and to look for appropriate resources so that they can create food safety plans for these operations.

\section{Who is it for?}

This training is for small farmers, produce vendors, and other people who deal with fresh fruit and vegetable production, distribution or processing.

\section{What does the training cover?}

The training program has six parts, and it works best if they are presented in order.

Part 1 consists of an introduction and an introductory slide show about the P.A.C.E. principles.

Part 2, "The Buck Stops Here," is an activity that demonstrates the consequences of foodborne illness outbreaks, highlights the real threat of lawsuits and shows the number of points from farm to fork where contamination can occur.

Part 3 uses a set of three short video clips titled "What's Wrong with This Picture?" to allow participants to identify incorrect practices.

Part 4 is an activity based on a farm map that allows participants to identify potential microbial hazard spots on the farm.

Part 5, "Passing along Best Practices," asks participants to think critically about ways that they can encourage behaviors to enhance food safety on their own operations.

1. This document is FCS8841, one of a series of the Family Youth and Community Sciences Department, Florida Cooperative Extension Service, Institute of Food and Agricultural Sciences, University of Florida. Original publication date October 5, 2007. Visit the EDIS Web Site at http://edis.ifas.ufl.edu.

2. Brian Lapinski, graduate student, Amy Simonne, associate professor, and M.E. Swisher, associate professor, Department of Family, Youth and Community Sciences, Institute of Food and Agricultural Sciences, University of Florida, Gainesville, 32611.

The Institute of Food and Agricultural Sciences (IFAS) is an Equal Opportunity Institution authorized to provide research, educational information and other services only to individuals and institutions that function with non-discrimination with respect to race, creed, color, religion, age, disability, sex, sexual orientation, marital status, national origin, political opinions or affiliations. U.S. Department of Agriculture, Cooperative Extension Service, University of Florida, IFAS, Florida A. \& M. University Cooperative Extension Program, and Boards of County Commissioners Cooperating. Larry Arrington, Dean 
Part 6 is a resource guide.

\section{How does it work?}

The entire content of the training program is found on the Small Farm Food Safety: Fresh Produce $D V D$.* Each part listed above is in a separate file on the DVD. Once opened, each part includes a list of needed materials and instructions about how to lead the exercise. The training is designed for instructors to move through these exercises in order from Part 1 through Part 5.

\section{How long will it take?}

The training with all five parts lasts approximately one hour and fifteen minutes. A number of the parts include room for group discussion and shared ideas. The trainer's methods for facilitating this discussion and the dynamics of the individual groups will affect the length of the training. As the trainer, feel free to adjust the program as you see fit. If you need to shorten the training, you may want to reduce the length of Part 2 by eliminating one or two of the scenarios.

\section{Where do I get more information?}

To obtain additional information or to get more training about food safety at the farm level, contact your local County office or the Extension food safety specialists at the University of Florida Institute of Food and Agricultural Sciences (http://solutionsforyourlife.ufl.edu/) or at the United States Food and Drug Administration (http://www.fda.gov/).

To obtain copies of the DVD that accompanies this publication, please contact the IFAS Extension Bookstore at 1-800-226-1764 or order online at www.ifasbooks.com. 